\title{
Profil Protein Isolat Bakteri Resisten Merkuri Dari Pertambangan Emas Rakyat Di Desa Pongkor, Bogor-Jawa Barat, Indonesia
}

\author{
Profile Protein of Mercury-Resistant Bacteria Isolate from People's Gold Mining at Bogor- \\ West Java, Indonesia
}

Patricia $^{1}$ dan Wahyu Irawati ${ }^{2 *}$

${ }^{1}$ Program Studi Biologi, Fakultas sains dan Matematika, Universitas Pelita Harapan Jalan M.H. Thamrin Boulevard 1100, Lippo Karawaci, Tangerang 15811, Indonesia

${ }^{2}$ Program Studi Biologi, Fakultas Ilmu Pendidikan, Universitas Pelita Harapan

Jalan M.H. Thamrin Boulevard 1100, Lippo Karawaci, Tangerang 15811, Indonesia

Email:w.irawati3@gmail.com*Penulis untukkorespondensi

\begin{abstract}
Mercury pollution due to gold mining at Pongkor Village can threaten the life of organisms because mercury is toxic. Bioremediation can be considered to reduce mercury concentration in the water. The mercury-resistant bacteria can be isolated from the area and may be developed as mercury bioremediation agents. This study aims to isolate mercury-resistant bacteria, test their resistance to mercury, and conduct protein profile studies after mercury induction. The mercury-resistant bacteria were isolated from soil samples in the Pongkor Village gold mining area and the isolate resistance to $\mathrm{HgCl} 2$ was measured based on the Minimum Inhibitory Concentration (MIC) value. The protein profile was analyzed using SDS PAGE gel electrophoresis. The results showed that two of the most resistant bacterial isolates to mercury were HgP1 and HgP2 with MIC value was 575 ppm. The protein profile showed that mercury induced decreased protein synthesis under normal conditions and increased synthesis of one protein suspected to play a role in the mechanism of bacterial resistance to mercury.
\end{abstract}

Keywords: HgP1, HgP2, mercury, protein profile, resistant

Abstrak

Pencemaran merkuri akibat pertambangan emas di Desa Pongkor dapat mengancam kehidupan organisme karena merkuri bersifat toksik sehingga harus dipikirkan cara bioremediasi yang dapat menurunkan konsentrasi merkuri di perairan. Bakteri resisten merkuri dapat diisolasi dari daerah tersebut dan dapat dikembangkan sebagai agen bioremediasi merkuri. Penelitian ini bertujuan untuk mengisolasi bakteri resisten merkuri, menguji resistensinya terhadap merkuri, serta melakukan studi profil protein setelah penginduksian merkuri. Bakteri resisten merkuri diisolasi dari sampel tanah di area pertambangan emas rakyat Desa Pongkor dan resistensi isolat terhadap $\mathbf{H g C l}_{2}$ diukur berdasarkan nilai Minimum Inhibitory Concentration (MIC). Profil protein dianalisis dengan menggunakan SDS PAGE gel elektroforesis. Hasil penelitian menunjukkan adanya dua isolat bakteri yang paling resisten terhadap merkuri yaitu $\mathrm{HgP1}$ dan $\mathrm{HgP2}$ dengan nilai MIC sebesar 575 ppm. Hasil profil protein menunjukkan bahwa penginduksian merkuri mengakibatkan penurunan sintesis protein pada kondisi normal dan peningkatan sintesis suatu protein yang diduga berperan dalam mekanisme resistensi bakteri tersebut terhadap merkuri.

Kata kunci : HgP1, HgP2, merkuri, profil protein, resisten

Diterima: 24 Juni 2016, disetujui: 05 Agustus 2016

\section{Pendahuluan}

Desa Pongkor merupakan suatu daerah yang tercemar merkuri karena adanya aktivitas pertambangan emas. Dalam PP No.18 tahun 1999 tentang Pengelolaan Limbah Bahan Berbahaya dan Beracun, nilai ambang batas untuk merkuri adalah 0,01 ppm, sedangkan 
sampel tanah di daerah pertambangan emas rakyat di daerah Pongkor memiliki rata-rata konsentrasi merkuri sebesar 220 ppm (Hidayati dkk, 2009; Juliawan, 2006; Ardiwilaga dkk, 1998).

Pencemaran merkuri merupakan salah satu kasus pencemaran lingkungan yang serius dan memiliki dampak negatif bagi kesehatan manusia. Hal ini disebabkan karena merkuri merupakan senyawa yang toksik dan memiliki afinitas yang sangat kuat terhadap kelompok thiol dari protein (Zeyaullah dkk, 2010). Merkuri dapat masuk ke rantai makanan dan jika terkonsumsi oleh manusia dalam jangka panjang dapat menyebabkan dampak yang buruk bagi kesehatan manusia, seperti melemahnya sistem saraf, kerusakan permanen pada otak yang mengakibatkan tremor, kerusakan paru-paru, ginjal, kulit, iritasi mata, pengurangan daya ingat, pendengaran atau penglihatan, menyebabkan janin cacat bahkan meninggal (Kiyono dan Hou, 2006). Mengingat dampak pencemaran merkuri bagi kesehatan manusia maka perlu dipikirkan cara pengolahan limbah yang dapat menurunkan konsentrasi merkuri di daerah tercemar.

Pengolahan limbah secara biologis akhirakhir ini banyak dikembangkan karena lebih murah dan ramah lingkungan dibandingkan secara kimia. Penelitian dalam bidang mikrobiologi lingkungan telah menemukan adanya bakteri yang memiliki sifat resistensi terhadap merkuri dan dapat membersihkan merkuri dari lingkungan tercemar. Menurut Nascimento dan Souza (2003), sifat resistensi bakteri terhadap merkuri secara genetis dikendalikan oleh gen operon mer yang menyandi detoksifikasi $\mathrm{Hg}^{2+}$ secara enzimatis menjadi logam merkuri yang tidak toksik. Bakteri resisten terhadap merkuri dapat menghasilkan enzim organomerkuriliase (MerB) yang mengkatalisis pemutusan ikatan merkurikarbon sehingga dihasilkan senyawa organik dan ion $\mathrm{Hg}^{2+}$. Rojas dkk (2011) mengatakan bahwa, ion $\mathrm{Hg}^{2+}$ selanjutnya direduksi menjadi $\mathrm{Hg}^{0}$ oleh enzim merkuri reduktase. Bentuk $\mathrm{Hg}^{0}$ merupakan bentuk yang bersifat kurang toksik serta mudah menguap sehingga dapat dievaporasikan dari sel bakteri dan lingkungannya. Mekanisme resistensi bakteri tersebut secara awal dapat dilihat dari perubahan profil protein isolat bakteri setelah penginduksian merkuri.

Bakteri resisten merkuri dapat diisolasi dari lingkungan yang terkontaminasi merkuri dan bakteri tersebut sangat potensial untuk dijadikan agen dalam upaya bioremediasi lingkungan yang tercemar merkuri (Zeyaullah dkk, 2010). Pemahaman tentang karakteristik fisiologis dan studi profil protein bakteri resisten merkuri merupakan penelitian awal agar bakteri tersebut dapat dimanfaatkan secara optimal dalam upaya bioremediasi lingkungan yang tercemar merkuri. Penelitian ini bertujuan untuk melakukan isolasi, uji resistensi, serta mengetahui profil protein bakteri resisten merkuri.

\section{Metode Penelitian}

\section{Galur Bakteri dan Medium Pertumbuhan}

Bakteri resisten merkuri diisolasi dari sampel tanah di area pertambangan emas rakyat di Desa Pongkor, Kabupaten Bogor, Jawa Barat. Medium cair dibuat dengan melarutkan 2 gram Luria Bertani dalam $100 \mathrm{ml}$ akuades. Medium padat dibuat dengan menambahkan 1,5\% agar oxoid. Medium disterilkan dengan autoklaf suhu $121^{\circ} \mathrm{C}$, tekanan $1 \mathrm{~atm}$, selama 15 menit. Larutan stok merkuri berupa $\mathrm{HgCl}_{2}$ dibuat dengan konsentrasi 50.000 ppm dan ditambahkan ke dalam medium yang telah disterilkan (Irawati dkk, 2012).

\section{Isolasi dan Seleksi Bakteri Resisten Merkuri}

Isolasi bakteri resisten merkuri dilakukan dengan metode sebar pada medium agar Luria Bertani (LB) ditambah dengan 100 ppm merkuri $\left(\mathrm{HgCl}_{2}\right)$. Sampel tanah dari area pertambangan emas yang tercemar merkuri dimasukkan ke dalam media Luria Bertani (LB) cair $500 \mathrm{ml}$ kemudian digojog selama 24 jam. Sampel tanah dilarutkan dengan air steril dengan pengenceran $10^{0}, 10^{-1}, 10^{-2}, 10^{-3}$, dan $10^{-4}$ kemudian masingmasing suspensi dari pengenceran tersebut diambil dan disebarkan pada media agar Luria Bertani (LB) yang mengandung $\mathrm{HgCl}_{2} 100$ ppm dan diinkubasi pada suhu $37^{\circ} \mathrm{C}$ selama 24 jam.

Koloni yang tumbuh diseleksi dan diberi kode kemudian dilakukan pemurnian sehingga diperoleh koloni tunggal. Pemurnian isolat 
bakteri dilakukan dengan mengambil koloni yang terpisah dan tampak jelas berbeda dengan jarum ose dan digoreskan pada cawan petri berisi medium agar LB yang mengandung $\mathrm{HgCl}_{2}$ $100 \mathrm{ppm}$, kemudian diinkubasi pada suhu $37^{\circ} \mathrm{C}$ selama 24 jam. Koloni tunggal diambil dan ditanam pada medium agar miring yang mengandung $\mathrm{HgCl}_{2} 100$ ppm.

\section{Pengamatan Morfologi Koloni dan Sel}

Pengamatan morfologi yang dilakukan dalam penelitian ini meliputi morfologi koloni dan morfologi sel dengan pewarnaan Gram. Pengamatan morfologi koloni dilakukan secara visual terhadap bentuk koloni, warna koloni, bentuk tepian dan elevasi. Pewarnaan Gram dilakukan dengan beberapa tahapan. Pewarnaan Gram dilakukan menurut Madigan dkk. (2009). Gelas benda yang sudah ditetesi dengan air dioleskan dengan koloni isolat bakteri kemudian dikering anginkan dan difiksasi di atas bunsen. Sampel ditetesi dengan kristal violet dan didiamkan selama satu menit kemudian dibilas dengan air mengalir. Larutan iodin diteteskan pada sampel dan didiamkan selama satu menit kemudian dibilas dengan air mengalir. Sampel ditetesi dengan decolorant sampai warna ungu berhenti terlepas dari sampel kemudian dibilas dengan air mengalir. Sampel ditetesi dengan safranin dan didiamkan selama satu menit kemudian dibilas dengan air mengalir dan dikeringkan.

Morfologi sel yang diamati meliputi klasifikasi Gram dan bentuk sel bakteri yang diamati di bawah mikroskop cahaya Carl Zeiss dengan perbesaran lensa objektif 100 kali yang disambungkan dengan kamera Canon PowerShot A640.

\section{Pengujian Resistensi Bakteri Terhadap Merkuri}

Pengujian resistensi bakteri terhadap merkuri dilakukan dengan menentukan nilai Minimum Inhibitory Concentration (MIC). Pengujian MIC dilakukan secara bertahap pada medium agar LB yang masing-masing mengandung berbagai konsentrasi $\mathrm{HgCl}_{2}$, yaitu dari 25-600 ppm dengan kisaran 25 ppm. Pengujian MIC dilakukan dengan metode streak plate sampai tidak ada koloni yang tumbuh pada medium. Konsentrasi awal $\mathrm{HgCl}_{2}$ yang digunakan adalah $25 \mathrm{ppm}$. Larutan stok $\mathrm{HgCl}_{2}$ yang digunakan adalah $50.000 \mathrm{ppm}$ yang dilarutkan pada air steril dan disterilisasi dengan autoklaf pada $121^{\circ} \mathrm{C}, 15$ psi selama 15 menit. Konsentrasi paling rendah dari $\mathrm{HgCl}_{2}$ yang dapat menghambat pertumbuhan bakteri merupakan nilai MIC yang ditentukan setelah 48 jam inkubasi pada $37^{\circ} \mathrm{C}$ (Raja dkk, 2006).

\section{Profil Protein Intraseluler Isolat Bakteri Setelah Penginduksian Merkuri}

Preparasi sel dilakukan menurut Harwood dan Gordon (1990). Kultur bakteri (1 ml) diinokulasikan ke dalam $25 \mathrm{ml}$ medium LB dan diinkubasi pada suhu $37^{\circ} \mathrm{C}$. Kultur bakteri dipanen pada saat tertentu dilihat dari kurva pertumbuhan bakteri. Kultur disentrifugasi 4.000 rpm selama 15 menit untuk menghsilkan supernatan (medium pertumbuhan) dan pellet (sel). Pellet dicuci dengan buffer fosfat $\mathrm{pH} 7$ untuk menghilangkan medium yang tersisa sehingga dihasilkan sel bebas medium. Sel disuspensikan ke dalam $25 \mathrm{ml}$ buffer fosfat $\mathrm{pH} 7$ kemudian disonikasi selama 45 detik (OD bakteri $=0,8$ ) untuk memecah sel secara mekanik. Ekstrak hasil sonikasi disentrifugasi $13.000 \mathrm{rpm}$ selama 5 menit untuk menghasilkan supernatan (protein intraseluler) dan pellet (pecahan membran dan dinding sel). Supernatan digunakan untuk analisis protein intraseluler.

Sampel dipekatkan dengan menggunakan aseton (perbandingan 1:2). Sampel diinkubasi pada suhu $-20^{\circ} \mathrm{C}$ selama satu malam. Sampel disentrifugasi dengan kecepatan 13.000 rpm selama 10 menit untuk memisahkan pellet (protein intraseluler) dan supernatan (aseton). Pellet dikeringanginkan selama \pm 2 jam pada $20^{\circ} \mathrm{C}$ dan diresuspensi dengan buffer fosfat $\mathrm{pH} 7$ (Caldwell \& Lattemann, 2004).

Protein intraseluler dielektroforesis dengan menggunakan Sodium Dodecyl Sulfate Poly-acrylamide Gel Electrophoresis (SDSPAGE) menurut metode Laemly (1970). Gel terdiri dari dua bagian, yaitu stacking gel dan gel pemisah. Konsentrasi acrylamide pada stacking gel $4 \%$ dan pada resolving gel $12 \%$. Tebal gel $1,5 \mathrm{~mm}$ dengan tegangan konstan $200 \mathrm{~V}$. Komposisi larutan stacking gel terdiri dari 30\% acrylamide: $0,8 \%$ bis-acrylamide; $1 \mathrm{M}$ Tris- $\mathrm{HCl}$ pH 6,8; 10\% Sodium Dodecyl Sulfate (SDS); tetrametilendiamine (TEMED); dan $10 \%$ 
ammonium persulfat (APS). Komposisi larutan gel pemisah sama dengan stacking gel tetapi $1 \mathrm{M}$ Tris- $\mathrm{HCl}$ yang digunakan adalah dengan $\mathrm{pH} 8,6$. Sampel $(28 \mu \mathrm{l})$ diinjeksikan ke dalam masingmasing sumuran pada stacking gel. Running buffer yang digunakan untuk SDS-PAGE adalah running buffer (1X). Running buffer dibuat dengan mencampurkan Tris dengan glisin dan Sodium Dodecyl Sulfate (SDS) beserta $\mathrm{dH}_{2} \mathrm{O}$. Sample buffer dibuat dengan mencampurkan Tris $\mathrm{HCl} 1 \mathrm{M}$ pH 6,8 dengan gliserol, 10\% Sodium Dodecyl Sulfate (SDS), 2merkaptoetanol, bromophenol blue, dan $\mathrm{dH}_{2} \mathrm{O}$. Larutan dihomogenisasikan menggunakan stirrer dan disimpan pada suhu $4^{\circ} \mathrm{C}$. Stain solution dibuat dengan mencampurkan coomassie blue R-250 dengan metanol, dan $\mathrm{dH}_{2} \mathrm{O}$. Larutan ini kemudian dihomogenisasikan dengan menggunakan stirrer dan ditambahkan dengan asam asetat glasial. Destain solution dibuat dengan mencampurkan metanol dengan asam asetat glasial beserta $\mathrm{dH}_{2} \mathrm{O}$. Larutan dihomogenisasikan menggunakan stirrer.

\section{Hasil dan Pembahasan}

\section{Isolasi dan Karakterisasi Bakteri Resisten Merkuri}

Hasil isolasi bakteri resisten merkuri dari tanah di Desa Pongkor pada medium yang mengandung $100 \mathrm{ppm} \quad \mathrm{HgCl}_{2}$ menunjukkan adanya dua macam isolat. Isolat tersebut masingmasing diberi kode isolat $\mathrm{HgP} 1$ dan $\mathrm{HgP} 2$. Pemilihan konsentrasi $\mathrm{HgCl}_{2}$ sebesar 100 ppm didasarkan pada tingkat pencemaran merkuri di Desa Pongkor yang sudah melebihi ambang batas yaitu 200 ppm (Hidayati dkk, 2009) sehingga diharapkan pada tahapan isolasi ini hanya diperoleh isolat (Gambar 1.) yang paling resisten. Karakterisasi morfologi koloni isolat HgP1 dan HgP2 dapat dilihat pada Tabel 1.

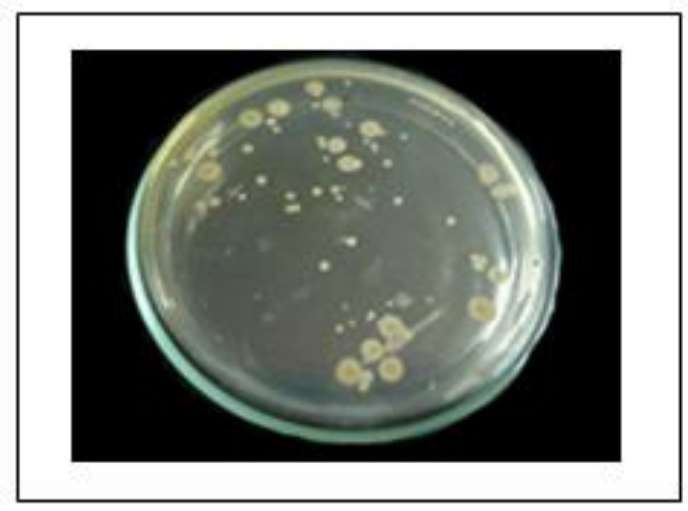

Gambar 1. Pertumbuhan bakteri dari sampel tanah pada medium LB agar yang

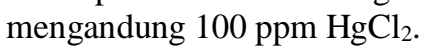

Tabel 1. Morfologi koloni isolat bakteri resisten merkuri

\begin{tabular}{|c|c|c|c|c|c|}
\hline \multirow[b]{2}{*}{$\begin{array}{l}\text { Kode } \\
\text { Isolat }\end{array}$} & \multicolumn{4}{|c|}{ Morfologi Koloni } & \multirow[b]{2}{*}{$\begin{array}{c}\text { Hasil } \\
\text { pewarnaan } \\
\text { Gram } \\
\end{array}$} \\
\hline & Warna koloni & $\begin{array}{c}\text { Bentuk } \\
\text { koloni }\end{array}$ & Tepi koloni & $\begin{array}{l}\text { Elevasi } \\
\text { koloni }\end{array}$ & \\
\hline$\overline{\mathrm{HgP1}}$ & $\begin{array}{l}\text { Kuning translucent, bagian tengah berwarna } \\
\text { kuning kehitaman apabila konsentrasi } \mathrm{HgCl}_{2} \\
\text { semakin tinggi }\end{array}$ & Irregular & Undulate & Raised & Negatif \\
\hline HgP2 & $\begin{array}{l}\text { Putih kuning translucent, bagian tengah } \\
\text { berwarna lebih gelap jika konsentrasi } \mathrm{HgCl}_{2} \\
\text { semakin tinggi }\end{array}$ & Irregular & Undulate & Raised & Negatif \\
\hline
\end{tabular}

Keterangan: Pengamatan morfologi koloni dilakukan dengan melihat warna, bentuk, tepi, dan elevasi koloni. 
Pengamatan morfologi sel dengan pewarnaan Gram menunjukkan bahwa isolat HgP1 dan HgP2 merupakan bakteri Gram negatif yang berbentuk batang. Santi \& Goenadi (2009) mengatakan bahwa bakteri Gram negatif menunjukkan toleransi terhadap logam berat yang lebih besar daripada Gram positif karena memiliki struktur dinding sel yang lebih kompleks yang mampu mengikat dan mengimobilisasi ion logam termasuk $\mathrm{Hg}^{2+}$. Menurut Madigan dkk (2009) dan Nies (1999) struktur dinding sel bakteri Gram negatif tersusun atas peptidoglikan yang tipis, membran luar (tersusun atas fosfolipid, lipoprotein, lipopolisakarida, protein), dan protein perifer. Bagian yang sangat berperan dalam menanggapi toksisitas terhadap logam berat adalah struktur kompleks yang terdapat pada bagian membran luar dari bakteri Gram negatif.

Hal ini sejalan dengan penelitian sebelumnya yaitu pada genus Serratia, Shigella, Enterobacter (Shovitri dkk, 2010), dan Pseudomonas (Jaysankar dkk, 2008) merupakan bakteri Gram negatif yang telah banyak dilaporkan sebagai bakteri resisten merkuri. Santi \& Goenadi (2009) juga melaporkan bahwa bakteri Gram negatif lebih banyak dijumpai resisten terhadap logam berat dibandingkan dengan bakteri Gram positif.

\section{Pengujian Resistensi Bakteri Terhadap Merkuri}

Hasil pengujian resistensi berdasarkan nilai MIC menunjukkan bahwa batas minimum konsentrasi yang mulai menghambat pertumbuhan isolat $\mathrm{HgP} 1$ dan $\mathrm{HgP} 2$ (Gambar 2 dan 3) adalah $575 \mathrm{ppm} \mathrm{HgCl}_{2}$. Hal ini menunjukkan bahwa isolat $\mathrm{HgP} 1$ dan $\mathrm{HgP} 2$ memiliki resistensi 7 kali lipat lebih tinggi dibandingkan hasil penelitian sebelumnya. Mortazavi dkk (2005) melaporkan bahwa Pseudomonas putida yang ditumbuhkan pada media Pepton broth dengan suhu $37^{\circ} \mathrm{C}$ memiliki MIC sebesar 80 ppm $\mathrm{HgCl}_{2}$.

Tingginya resistensi isolat $\mathrm{HgP1}$ dan $\mathrm{HgP} 2$ terhadap $\mathrm{HgCl}_{2}$ mungkin disebabkan oleh adanya suatu mekanisme resistensi isolat bakteri terhadap merkuri seperti yang terjadi pada bakteri resisten merkuri lain yang pernah dilaporkan yaitu dengan cara mengakumulasi dan mendetoksifikasi ion $\mathrm{Hg}^{2+}$ menjadi $\mathrm{Hg}^{0}$
(Ruiz dkk, 2011; Rojas dkk, 2011). Kemampuan isolat $\mathrm{HgP} 1$ dan $\mathrm{HgP} 2$ untuk tumbuh dengan keberadaan $\mathrm{HgCl}_{2}$ yang sangat tinggi berpotensi untuk diaplikasikan dalam proses pengolahan limbah yaitu mikroorganisme secara langsung terlibat dalam dekomposisi material organik (Raja dkk, 2009).

Gambar 3E dan 3F menunjukkan bahwa penambahan 250-300 ppm $\mathrm{HgCl}_{2}$ menyebabkan perubahan warna koloni isolat $\mathrm{HgP} 2$ menjadi kehitaman. Perubahan warna koloni menunjukkan mekanisme resistensi dengan cara akumulasi seperti yang terjadi pada bakteri transgenik Escherichia coli (Ruiz dkk, 2011) sebelum terjadinya proses detoksifikasi untuk mereduksi ion $\mathrm{Hg}^{2+}$ menjadi ion $\mathrm{Hg}^{0}$ (Nascimento \& Souza, 2003).

Menurut Ruiz dkk. (2011), perubahan morfologi koloni menjadi kehitaman pada bakteri transgenik Escherichia coli disebabkan protein metallothionein di dalam sitoplasma yang berperan mengikat logam berat. Metallothionein dapat meningkatkan resistensi dan akumulasi bakteri terhadap logam berat. Metallothionein merupakan protein pengikat logam yang memiliki berat molekul rendah dan kaya akan sistein. Protein ini dikodekan oleh gen $\mathrm{mt}$ yang dapat mengikat ion logam dalam bentuk yang tidak aktif. Perubahan warna koloni menjadi hitam secara selular digunakan sebagai penanda untuk menentukan perkembangan proses bioremediasi yang sedang terjadi. Pengaruh pemberian merkuri terhadap perubahan sintesis protein isolat bakteri $\mathrm{HgP} 1$ dapat diamati pada studi profil protein bakteri setelah penginduksian merkuri.

\section{Profil Protein Intraseluler Isolat Bakteri Setelah Penginduksian Merkuri}

Bakteri yang terpapar merkuri konsentrasi tinggi akan menanggapi cekaman dengan mengembangkan beberapa mekanisme resistensi yang melibatkan protein maupun enzim (Hughes \& Poole, 1989). Profil protein intraseluler isolat bakteri HgP1setelah penginduksian merkuri dapat dilihat pada Gambar 4.

Gambar 4 menunjukkan bahwa pita protein tanpa penginduksian dan setelah penginduksian dengan logam berat menunjukkan adanya perbedaan ekspresi gen. Pada kondisi tanpa penginduksian dengan merkuri, pita 
protein yang dihasilkan lebih banyak jika dibandingkan yang diinduksi dengan merkuri. Hal ini menunjukkan bahwa protein seluler merupakan salah satu target utama dari logam berat (Gamal, 2008). Penginduksian merkuri menyebabkan protein yang berperan dalam kondisi normal mengalami penurunan ataupun tereleminasi (ditunjukkan dengan panah 1, 2, 3 dan 5) serta menyebabkan adanya peningkatan sintesis satu jenis protein yang diduga erat berkaitan dengan mekanisme resistensi terhadap merkuri (ditunjukkan dengan panah 4).

Hasil profil protein ini sama dengan hasil penelitian sebelumnya yang dilakukan pada Cyprinus carpio (Gamal, 2008) dan Irawati dkk
(1997) pada isolat bakteri resisten tembaga galur B4. Cyprinus carpio mengalami perubahan ekspresi protein ketika diinduksi dengan kadmium. Perubahan yang terjadi adalah eliminasi beberapa pita protein dan protein secara keseluruhan ataupun pembentukan pita protein yang baru. Konsentrasi kadmium yang tinggi dapat mengeleminasi lima belas pita protein dan pembentukan dua belas pita protein yang baru (Gamal, 2008). Isolat B4 mengalami penurunan sintesis protein yang berperan dalam kondisi normal dan mensintesis dua protein spesifik setelah penginduksian dengan tembaga (Irawati dkk, 1997).

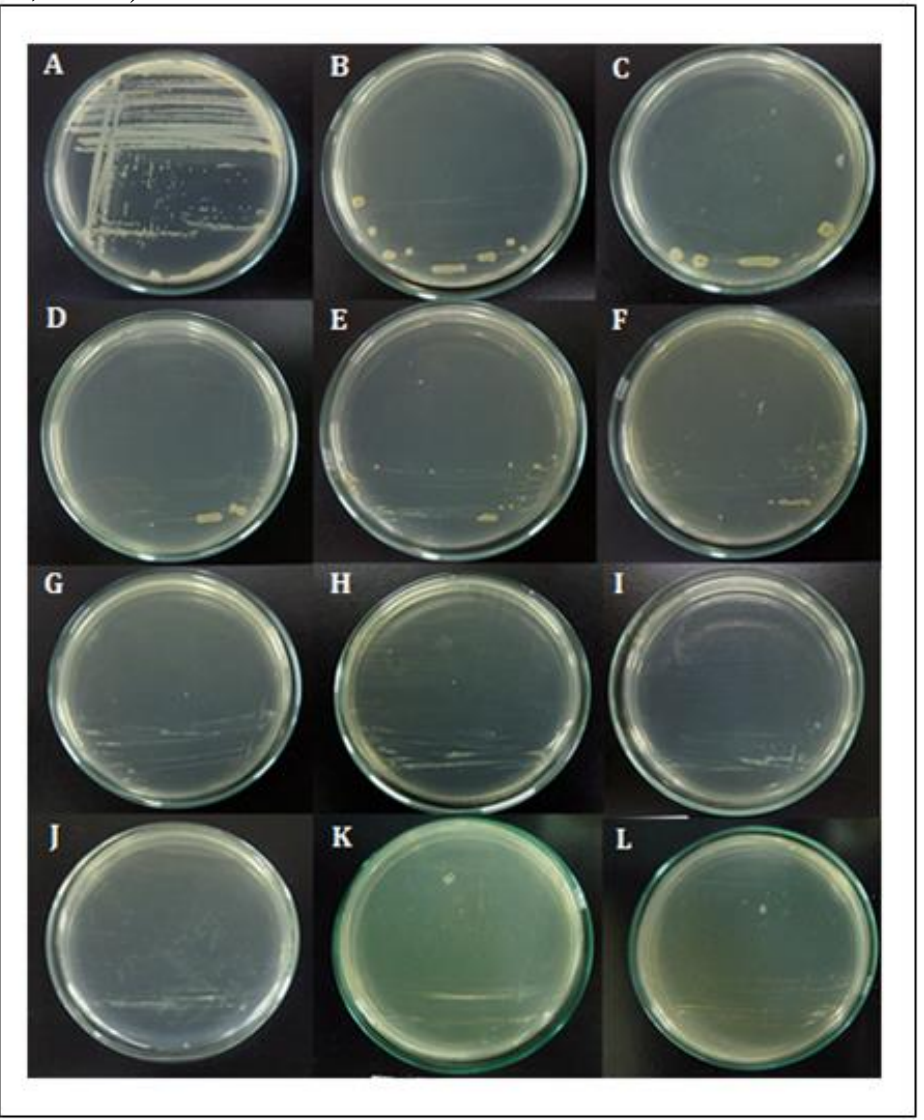

Gambar 3. Hasil pengujian MIC pada isolat HgP2.

Uji resistensi dilakukan dengan menentukan Minimum Inhibitory Concentration (MIC) secara bertahap pada medium agar LB yang mengandung berbagai konsentrasi $\mathrm{HgCl}_{2}$ dengan cara streak plate. Konsentrasi paling rendah dari $\mathrm{HgCl}_{2}$ yang dapat menghambat pertumbuhan bakteri merupakan nilai MIC yang ditentukan setelah 48 jam inkubasi pada $37^{\circ} \mathrm{C}$. (A) Kontrol tanpa pemberian $\mathrm{HgCl}_{2}$; (B) $100 \mathrm{ppm} \mathrm{HgCl}_{2}$; (C) $150 \mathrm{ppm} \mathrm{HgCl}_{2}$; (D) $200 \mathrm{ppm} \mathrm{HgCl}_{2}$; (E) 250 ppm $\mathrm{HgCl}_{2}$; (F) 300 ppm $\mathrm{HgCl}_{2}$; (G) 350 ppm $\mathrm{HgCl}_{2}$; (H) 400 ppm $\mathrm{HgCl}_{2}$; (I) 450 ppm $\mathrm{HgCl}_{2}$; (J) 500 ppm $\mathrm{HgCl}_{2}$; (K) $550 \mathrm{ppm}$ $\mathrm{HgCl}_{2}$; (L) 575 ppm $\mathrm{HgCl}_{2}$. Tanda panah putih menunjukkan perubahan warna koloni. 


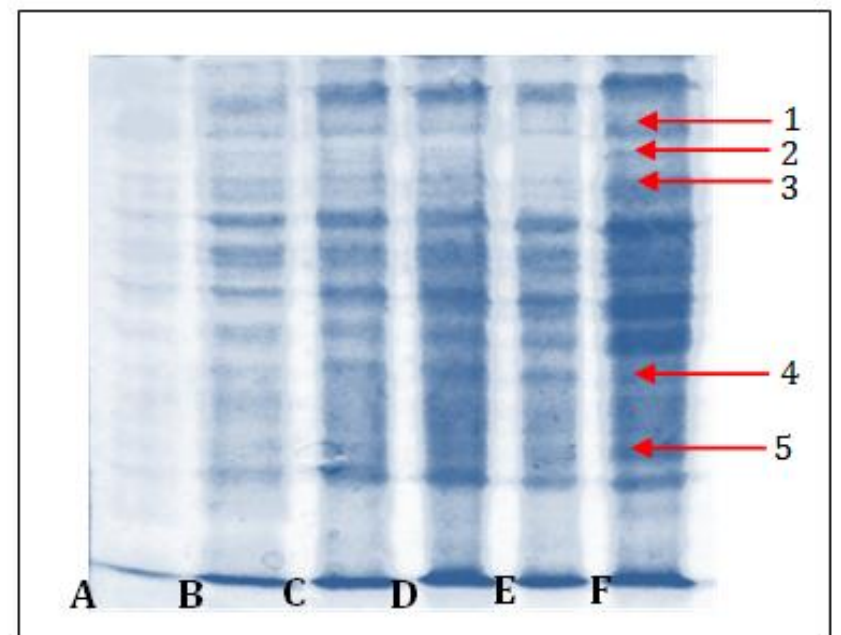

Gambar 4. Profil protein intraseluler isolat bakteri $\mathrm{HgP1}$ pada pemberian 50 dan $100 \mathrm{ppm} \mathrm{HgCl}_{2}$ beserta kontrol.

Profil protein intraseluler isolat $\mathrm{HgP} 1$ dipisahkan dengan menggunakan SDS-PAGE gel elektroforesis dengan tegangan 200 volt selama 45 menit pada resolving gel $12 \%$ dan stacking gel 4\%. Protein intraseluler pada pemberian $50 \mathrm{ppm} \mathrm{HgCl}_{2}$ (A) $\mathrm{OD}=0,80$; (B) $\mathrm{OD}=2,00$; (C) $\mathrm{OD}=2,70$; Protein intraseluler pada pemberian 100 ppm $\mathrm{HgCl}_{2}$ (D) $\mathrm{OD}=2,60$; (E) $\mathrm{OD}=3,10$; (F) kontrol (tanpa pemberian $\mathrm{HgCl}_{2}$ ) dengan $\mathrm{OD}=2,09$. Tanda panah merah menunjukkan perubahan ekspresi protein.

Protein merupakan molekul efektor primer yang dipengaruhi oleh lingkungan, kondisi fisiologis dan patologi (Gamal, 2008). Sel memerlukan proses adaptasi dalam menanggapi kondisi cekaman. Selama proses adaptasi terjadi penyesuaian kecepatan dan arah rangkaian reaksi metabolik. Pengendalian ini mengakibatkan peningkatan atau penurunan jumlah enzim, perubahan macam enzim yang bekerja, dan pengendalian fungsi enzim yang sudah ada (Hochachka dan Somero, 1973).

\section{Simpulan}

Profil protein menunjukkan bahwa penginduksian merkuri mengakibatkan penurunan sintesis protein pada kondisi normal dan peningkatan sintesis suatu protein yang diduga berperan dalam mekanisme resistensi bakteri tersebut terhadap merkuri.

\section{Daftar Pustaka}

Ardiwilga, S., Marganingrum, D., Supriadidjaja, A. dan Sukmayadi, D. 1998. Pemantauan kualitas lingkungan di unit pertambangan emas Pongkor (PT Aneka Tambang). Laporan Penelitian Puslitbang Geoteknologi-LIPI. halaman. 67-77.

Caldwell, R.B. dan Lattemann, C.T. 2004. Simple and reliable method to precipitate proteins from bacterial culture supernatant. Applied and Environmental Microbiology, 70: 610-612.

Gamal, A.D.E. 2008. Protein profile changes in Chrococcus dispersus, Microcystis flos-aquae, and Microcoleus steenstryqii in response to cadmium treatments. Journal of King Abdulaziz University: Science, 20: 131-148.

Harwood, V.J. dan Gordon, A.S. 1990. Copper-induced production of copper binding supernatant protein by the marine bacterium Vibrio alginolyticus. Applied Environmental Microbiology, 56: 1327-1332. 


\section{Profil Protein Isolat Bakteri Resisten Merkuri}

Hidayati, N., Juhaeti, T. Dan Syarif, F. 2009. Mercury and cyanide contaminations in gold mine environment and possible solution of cleaning up by using phytoextraction. HAYATI Journal of Biosciences, 16: 88-94.

Hochachka, P.W. dan Somero, G.N. 1973. Strategies of Biochemical Adaptation. W.B. Saunders Comp: Philadelphia.

Hughes, M.N. dan Poole, R.K. 1989. Metals and Microorganisms. New York: Chapman and Hall.

Irawati, W., Yuwono, T., Hartiko, H. dan Joetono. 1997. Profil protein bakteri pengikat tembaga setelah penginduksian tembaga. Berkala Penelitian Pasca Sarjana Universitas Gadjah Mada, (10): 19-28.

Jaysankar, D., Ramaiah, N. dan Vardanyan, L. 2008. Detoxification of toxic heavy metals by marine bacteria highly resistant to mercury. Marine Biotechnology, 10: 471-477.

Juliawan, N. 2006. Pendataan penyebaran merkuri pada wilayah pertambangan di daerah Pongkor, Kabupaten Bogor, Provinsi Jawa Barat. Proceeding Pemaparan Hasil-hasil Kegiatan Lapangan dan Non Lapangan tahun 2006, Pusat Sumberdaya Geologi.

Kiyono, M. dan Hou, H.P. 2006. Genetic engineering of bacteria for environmental remediation mercury. Journal of Health Science, 52: 199204.

Laemly, U.K. 1970. Cleavage of structural protein during the assembly of the head bacteriophage $\mathrm{T} 4$. Nature, 227: 680-685.

Madigan, M. T., Martinko, J. M., Dunlap, P. V. dan Clark, D.P. 2009. Biology of Microorganisms, Twelfth edition. San Francisco: Pearson.

Mortazavi, S., Rezaee, A., Khavanin, A., Varmazyar, S. dan Jafarzadeh, M. 2005. Removal of mercuric chloride by a mercury resistant Pseudomonas putida strain. Journal of Biological Sciences, 5: 269-273.

Nascimento, A.M.A. dan Souza, E.C. 2003. Operon mer: bacterial resistance to mercury and potential for bioremediation of contaminated environments. Genetics and Molecular Research, 2: 92-101.
Nies, D.H. 1999. Microbial heavy-metal resistance. Applied Microbiology and Biotechnology, 51: 730-750.

Raja, C.E., Anbazhagan, K. dan Selvam, G.S. 2006. Isolation and characterization of a metalresistant Pseudomonas aeruginosa strain. World Journal of Microbiology and Biotechnology, 22: 577-585.

Raja, C.E., Selvam, G.S. dan Omine, K. 2009. Isolation, identification and characterization of heavy metal resistant bacteria from sewage. International Joint Symposium on Geodisaster Prevention and Geoenvironment in Asia. JSFukuoka: 205-211.

Rojas, L.A., Yanez, C., Gonzalez, M., Lobos, S., Smalla, K. dan Seeger, M. 2011. Characterization of the metabolically modified heavy metal-resistant Cupriavidus metallidurans strains MSR33 generated for mercury bioremediation. PLoS ONE, 6: 1-10.

Ruiz, O.N., Alvarez, D., Ruiz, G.G. dan Torres, C. 2011. Characterization of mercury bioremediation by transgenic bacteria expressing metallothionein and polyphosphate kinase. BioMed Central Biotechnology, 11: 82-89.

Santi, L.P. dan Goenadi, D.H. 2009. Potensi Pseudomonas fluorescens strain KTSS untuk bioremediasi merkuri di dalam tanah. Menara Perkebunan, 77: 110-124.

Shovitri, M., Zulaika, E. dan Koentjoro, M.P. 2010. Bakteri tanah merkuri dari Kali Mas Surabaya berpotensi sebagai agen bioremediasi merkuri. Berkala Penelitian Hayati, (4): 25-29.

Zeyaullah, Md., Islam, B. dan Ali, A. 2010. Isolation, identification, and PCR amplification of merA gene from highly mercury polluted Yamuna River. African Journal of Biotechnology, 9: 3510-3515. 